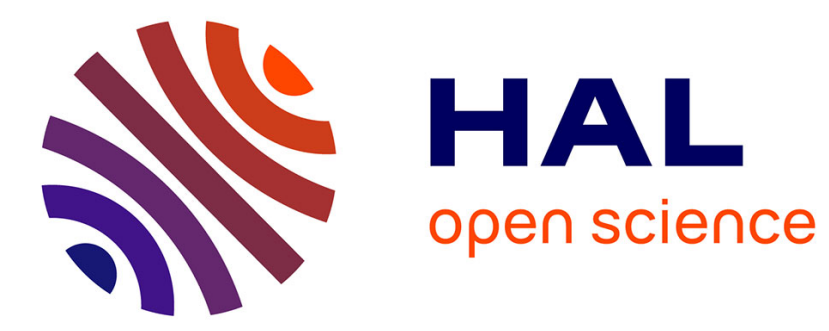

\title{
CROSSBREEDING EFFECTS IN PRACTICAL PIG PRODUCTION
}

\author{
G. Ral
}

\section{To cite this version:}

G. Ral. CROSSBREEDING EFFECTS IN PRACTICAL PIG PRODUCTION. Annales de génétique et de sélection animale, 1978, 10 (4), pp.604-605. hal-00893099

\section{HAL Id: hal-00893099 \\ https://hal.science/hal-00893099}

Submitted on 1 Jan 1978

HAL is a multi-disciplinary open access archive for the deposit and dissemination of scientific research documents, whether they are published or not. The documents may come from teaching and research institutions in France or abroad, or from public or private research centers.
L'archive ouverte pluridisciplinaire HAL, est destinée au dépôt et à la diffusion de documents scientifiques de niveau recherche, publiés ou non, émanant des établissements d'enseignement et de recherche français ou étrangers, des laboratoires publics ou privés. 


\title{
ÜBER DIE SCḦ̈TZUNG DER GENETISCHEN KOVARIANZKOMPONENTEN
}

\author{
L. DEMPFLE \\ Lehtstuhl f. Tierzucht der TU München, \\ $D-805^{\circ}$ Freising, Weihenstephan (W-Germany)
}

In der angewandten Tierzüchtung benötigt man zur Optimierung der Zuchtprogramme, zur Konstruktion von Selektionsindices usw. möglichst genaue Schätzwerte für die genetischen Varianzen und Kovarianzen.

Die zuverlässige Schätzung dieser genetischen Parameter ist praktisch nur bei großem Datenmaterial möglich und aus Kostengründen müssen sie fast immer aus Versuchen geschätzt werden, die für andere $Z$ wecke (genetischer Fortschritt) optimiert wurden. Einige der zur Schätzung der genetischen Kovarianzkomponenten möglicher Methođen werden im Hinblick auf thre Anwendbarkeit und Effizienz diskutiert.

\section{ANWENI,UNGSMÖGIICHKEITEN DER ZWEISTUFENSELEKTION IN DER TIERZUCHT}

\author{
S. KLEINSCHMIDT und P. GLODEK \\ Institut f. Tierzücht und Haustiergenetik der Universität Göttingen, \\ $D-3400$ Göttingen, Albrecht-Thaer-Weg I (W-Germany)
}

Der Erfolg einer zweistufigen Selektion nach der Wurfgröße beim Schwein wird unter speziellen Annahmen berechnet, die sich weitgehend an den derzeitigen Verhältnissen der deutschen Herdbuchzucht orientieren. Dabei ist eine zweistufige Selektion, die 35 p. roo der anfangs geprüften Sauen in einer zweiten Stufe prüft, einer einstufigen Selektion nach dem 2. Wurf überlegen.

\section{BREIDING PI,ANNING IN THE CONTEXT OF BUSINESS PLANNING}

\section{H. MOMM}

Institut $f$. Tierhaltung und Tierzüchtung, Universität Hohenheim, 70oo Stuttgart 70 (W-Germany)

Consistent breeding planning requires far-reaching measures of practical organisation. Refering to business planning, which is guiding the breeding planning under all different conditions of business, the following can be said:

I. Breeding planning is like all plannings in business organisations part of the management process. Breeding planning has, therefore, to be seen in connexion with all other steps of the management process, i.e. the objective development and the accomplishment of plan.

2. In organizing breeding planning its integration in the process or management has to be considered. The planning specialists and the managers, therefore, have to work together closely and continuously in the respective planning organs.

3. Against the background of the criterions of business planning empirical investigations should be aimed at for the organisation of breeding planning. Therewith models of organisation from breeding practice could be constructed, which might be helpful in solving the problems.

\section{CROSSBREEDING EFFECTS IN PRACTICAI, PIG PRODUCTION}

\section{G. RAI , \\ (Sweden)}

A comparative investigation into the effects of crossbreeding between the two breeds Swedish Landrace and Scedish Yorkshire has been carried out on the basis of 33686 litters registered with the computerized sow litter recording scheme. The litters were farrowed during the period 
I Oct. I974 to I Oct. I975. The effects of crossbreeding were studied in single crosses, backcrosses, alternate back-crosses and in unsystematized crosses, regarding the numbers of piglets born, the numbers born alive, and the numbers surviving at an age of 2-6 weeks. For piglets born alive in the above-named crossbreeding types, the effects were $0.27,0.47,0.34$ and 0.20 respectively. The corresponding figures for survivors at an age of $2-6$ weeks were $0.33,0.55,0.42$ and 0.29 .

\author{
TESTIS GROWTH IN "POLISH MERINO" AND “ ILE-DE-FRANCE" RAMS \\ AND I'TS REI,ATIONSHIP WITH PROLIFICACY OF EWES \\ M. J. RADOMSKA, J. KLEWIEC and F. MAJZNER \\ Institute of Biological Bases of Animal Breeding \\ Agricultural University, ul. Rakowiecka 26/30, o2-528 Warsaw, Poland
}

Experiments were conducted in 1977 in the same state farm on 97 Polish Merino rams (49 single-borns and 48 twins) and 70 Ile-de-France rams (26 singles and 44 twins). Measurements of the testis diameter were carried out after Land's (I975) method at the ages of 6, Io and I4 weeks.

The correlation coefficients between body weight and the diameters of testes were: in Polish Merino $r=0,348$, in Ile-de-France $r=0,554$. Differences in dimensions of testes were significant as the effect of the parental birth-type.

\title{
SIDE EFFECTS OF SELECTION FOR BODY WEIGH IN LABORATORY MICE
}

\author{
Elzbieta MICHALSK $\check{A}$ \\ Institute of Biological Bases of Animal Breeding \\ Agricultural University, ul. Rakowiecka 26/3o, \\ 02-528 Warsaw, Poland
}

Observations were made on the growth and developmient of mouse lines obtained in long term selection for body weight on the 2 ist day of life, a control line and reciprocal crossbreds of all combinations of these lines. Individual body weights were recorded on days I, I2, 2 I, 42, 57 and 72 after birth. Approximate feed uptake and age at which the following developmental traits appeared were also recorded: appearance of external ears, opening of eyes, appearance of hair coat, nipples and opening of vagina.

It was found that long term selection for body weight on 2 ist day differentiated the growth ability of young individuals. The differences appeared only after weaning in the high weight mice in the form of compensatory growth. The effects of heterosis, as regards body weight in crossbreds, are slight and appear mainly in the perweaning period, this beeing seemingly connected with the mother's performance. Comparison of reciprocal crossbreds shows a superiority of the mother's performance of females of the control line over that low weight line and a smaller superiority of females of the high weight over those of low weight line and a lack of significant differences in mothers' performance between the high and low weight lines. Analysis of some developmental traits indicated a retardation in the development of the young from the low weight line and no response of the heavy weight line. The influence of the paternal and maternal lines was revealed as regards earlier time of eyes opening (prevalence of paternal line $C$ vs $L$, maternal line $C$ vs $L$ and $O$ ). This also concerned earlier time of sexual maturation of the females (prevalence of paternal line $O$ vs $I, C$ vs $O$ and maternal line $C$ vs $L$ and $O$ ).

\section{IDENTITY COEFFICIENTS AND GENETIC VARIABILITY IN THEORETICAI, GENETICS}

\author{
C. CHEVALET, M. GILLOIS \\ Labovatoive de Génétique cellulaive, \\ Centre de Recherches de Toulouse, I.N.R.A. \\ B.P. I2-3132o Castanet Tolosan, France
}

Definition, significance and computation rules of identity coefficients are reviewed with emphasis on their use in the quantitative genetics models. 